\title{
American Woodcock Singing-Ground Survey Sampling of Forest Type and Age
}

BRIAN G. TAVERNIA, ${ }^{1}$ The Nature Conservancy, Colorado Field Office, 2424 Spruce Street, Boulder, CO 80302, USA

MARK D. NELSON, USDA Forest Service, Northern Research Station, 1992 Folwell Avenue, St. Paul, MN 55108, USA

REBECCA RAU, U.S. Fish and Wildlife Service, Division of Migratory Bird Management, 11510 American Holly Drive, Laurel, MD 20708, USA

JAMES D. GARNER, USDA Forest Service, Northern Research Station, 1992 Folwell Avenue, St. Paul, MN 55108, USA

CHARLES H. PERRY, USDA Forest Service, Northern Research Station, 1992 Folwell Avenue, St. Paul, MN 55108, USA

\begin{abstract}
The American Woodcock Conservation Plan calls for halting and reversing declines of American woodcock (Scolopax minor) populations through creation and management of early successional forest (ESF). Counts of displaying male woodcock along routes of the American woodcock singing-ground survey (SGS) are used to assess regional population status and trends, and there is a need to assess whether SGS routes represent the region. We assessed whether individual SGS routes (330-m buffers) in the Boreal-Hardwood and Prairie-Hardwood Transitions of Minnesota, USA, represented land covers within local landscapes, defined using simulated 10-minute blocks, and whether the routes, in aggregate, represented land covers of our study region. Our land covers included non-forest classes, age-based ESF (20 years), and persisting classes for deciduous-mixed and evergreen forests and woody wetlands. We found that the median value of mean absolute differences (MAD) between percentages for route buffer and block cover classes was 3.78 percentage points. Twenty-two of $81(27 \%)$ route buffers had MAD values 5 percentage points. Within Minnesota, more of these routes (19 of 22) occurred in the Boreal-Hardwood Transition than in the Prairie-Hardwood Transition. Relative to local landscapes, route buffers most frequently and strongly underrepresented open water, barren land, evergreen ESF, persisting woody wetlands, and woody wetland ESF and over-represented developed land and grassland-pasture. When we compared routes in aggregate to our study region, the magnitude of percentage point differences for individual covers did not exceed 5, except for open water. Given the relatively small differences we observed, we conclude that SGS routes well represent land covers within our study region.
\end{abstract}

Proceedings of the American Woodcock Symposium 11: 227

KEY WORDS: aggregation, American woodcock, compositional analysis, early successional forest, forest disturbance, roadside survey, Scolopax minor, singing-ground survey, young forest

FUll PaPer Citation: Tavernia, B.G., Nelson, M.D., Rau, R., Garner, J.D., Perry, C.H. 2018. American Woodcock singing-ground survey sampling of forest type and age. The Journal of Wildlife Management, 82(8):1794-1802. https://doi. org/10.1002/jwmg.21537

1 email: brian.tavernia@tnc.org 